\title{
Preliminary biometrical analysis on three similar hippuritid species
}

\author{
Mauro Caffau \\ Dipartimento di Scienze Geologiche Ambientali e Marine, Università degli Studi di Trieste, \\ Via Eduardo Weiss 2 CAP 34127 Trieste \\ Mario Pleničar \\ Katedra za geologijo in paleontologijo NTF \\ Univerza v Ljubljani \\ Aškerčeva 2, 1000 Ljubljana, Slovenija
}

\begin{abstract}
The hippuritids species Hippuritella lapeirousei (Goldfuss, 1840), Hippuritella nabresinensis (Futterer, 1893) and Hippuritella heritschi (Küh, 1947) were studied through biometrical analysis. For this purpose, the areas of three morphological characters which are related by their biological functions (as described by Realy, 1992) were measured on transversal sections of lower valves. These morphometrical values are: a) shell area (Sa), b) inner area (Ia) and c) pillars area $(\mathrm{Pl}-\mathrm{P} 2 \mathrm{a})$. This analysis highlighted a morphological similarity between $H l$. nabresinensis and $H l$. heritschi, meanwhile the morphometric values for $H l$. lapeirousei showed to be different.
\end{abstract}

\section{Introduction}

The hippuritid species Hippuritella lapeirousei (Goldfuss, 1840), Hippuritella nabresinensis (Futterer, 1893) and Hippuritella heritschi (Kühn, 1947) are very similar from the morphological point of view. In fact, this topic was discussed in literature by different authors.

Douvillé (1891-97) observed a clear similarity between $\mathrm{Hl}$. lapeirousei and $\mathrm{Hl}$. nabresinensis and, later, Parona (1900) and Toucas (1903-1904) considered $\mathrm{Hl}$. nabresinensis as a synonim of $\mathrm{Hl}$. lapeirousei. However several authors observed a wide variability in the ornamentation of these species. Toucas (1903-1904) noted it analysing the lower valve of $\mathrm{Hl}$. lapeirousei. Successively, Pleničar (1975, 1994) and Vicens (1992) observed this variability between $\mathrm{Hl}$. nabresinensis and Hl. lapeirousei. Afterwards, Sladić-Trifunović $(1972,1978)$ and Laviano (1985) discussed the problem about the great similarity among the three species.

Thus, their similarity focuses on a still unsolved taxonomical problem. The aim of this paper is to discuss about this taxonomical problem through morphometric analysis carried out on specimens belonging to the three species. 


\section{Material}

Part of the morphometrical measures was obtained analysing the specimens of $H l$. Lapeirousei, $\mathrm{Hl}$. Nabresinensis and $H \mathrm{l}$. heritschi described in literature, including the holotypes of the three species (tables 1, 2, 3). Moreover, 300 lower valves of $\mathrm{Hl}$. nabresinensis coming from the area of the holotype (Aurisina/Nabrežina - Karst of Triest) have been analyzed (table 4). Forty-eight of them were selected in that they revealed an excellent state of conservation. Fifteen valves of $\mathrm{Hl}$. heritschi coming from Stranice and Senožeče (Slovenia) have been analysed and measured. These samples show similar morphological characters with respect to those of the holotype described by Kühn (1947).

Unfortunately it was no possible to carry out similar analysis with specimens of Hl. lapeirousei, because in the area of the Karst of Trieste (Italy) and Triest-Komen plain (Slovenia) this species is represented by scarce and bad-preserved specimens.

The studied valves of $H l$. nabresinensis and $H l$. heritschi are deposited in the collection of the "Istituto di Geologia e Paleontologia dell'Università di Trieste", and in the collection of the "Katedra za geologijo in paleontologijo univerze v Ljubljani", respectively, meanwhile those coming from Senožeče (Slovenia) have been kindly lent by doctor Bogdan Jurkovšek from his private collection.

The systematics and taxonomic aspects of the three species are shortly discussed below.

\section{Palaeontological description}

Familia Hippuritidae Gray, 1848

Genus Hippuritella Douvillé, 1908

Hippuritella lapeirousei (Goldfuss, 1840)

1891-97 Hippurites lapeirousei var. crassa Goldfuss - Douvillé, 222, pl. 24, fig. 10.

1900 Hippurites lapeirousei Goldfuss - Parona, 11, pl. 1, figs. 1-3.

1912 Orbignya lapeirousei var. crassa Goldfuss - Schubert, 62.

1975 Hippurites (Orbignya) lapeirousei Goldfuss - Pleničar, 87, pl. 1, fig. 10.

1981 Hippuritella lapeirousei (Goldfuss) - Sánchez 10, cum syn.

1992 Hippuritella lapeirousei (Goldfuss) - Vicens, 123.

1994 Hippuritella lapeirousei (Goldfuss) - Pleničar, 50, pl. 2, figs 9-10.

Taxonomical remarks: According to Douvillé (1891-97), Hl. lapeirousei is characterized by a cylindrical or cylindric-conical lower valve ornamented by longitudinal costae of variable wideness, which are separated by concave rounded canals. The distance between the costae varies among specimens coming from different geografical areas. The upper valve is covered by polygonal pores, which are arranged into regular and radial rows on the border of the valve.

The inner characters are the ligamental ridge, absent or hardly marked by a small inflexion in the outer layer of the shell, and the rounded pillars, which are slightly different between them. The cardinal apparatus is situated near the dorsal margin of the lower valve. The tooth $N$ is $\mathrm{X}$-shaped. The narrow and elongated alveolus of 
the anterior tooth is situated along the dorsal margin, while that of the posterior one is small and rounded. The miophore cavities are well developed.

Douvillé (1895) observed that "les caractéres de l'ornamentation extérieure, quoique d'une importance beaucoup moindre, peuvent être aussi d'une certain utilité pour distinguer ces espèces."

Douvillé (1895) defined the group of Hippuritella variabilis Munier-Chalmas, 1867 in which he included the following species: Hippuritella maestrei Vidal, 1878, Hippuritella variabilis and Hippuritella lapeirousei.

Sladić-Trifunović (1978) observed that the holotype of $H l$. lapeirousei is characterized by a conical valve, while the holotype of $\mathrm{Hl}$. nabresinensis is cylindrical.

Distribution: This species has been found in the Upper Campanian-Lower Maastrichtian in Spain in the areas of Montsec and Valencia, in Italy in the zones of Matese Mt. And Maiella Mt. (Pons \& Sirna, 1992) and at Stranice in the Maastrichtian (Slovenia) (Pleničar, 1994).

The transversal sections of the lower valves of the individuals of the species Hippuritella lapeirousei are presented on the plate 1, the morphometrical measures of the same individuals on the table 1 .

\section{Hippuritella nabresinensis (Futterer, 1893)}

1926 Hippurites (Orbignya) lapeirousei Goldfuss - Parona, 349.

1969 Hippurites nabresinensis acuticostatus Lupu - Lupu, 210, pl. 1.

1975 H. (Orbignya) nabresinensis Futterer - Pleničar, 107, pl. 1, fig. 2., textfig. 3.

1981 H. nabresinensis Futterer - Sánchez, 20, cum syn.

1982 H. nabresinensis Futterer - Czabalay, 80, pl. 10, fig. 5.

1982 H. nabresinensis Futterer - Accordi et al., 770, pl. 7, figs. 8, 10.

1985 H. nabresinensis Futterer - Laviano, 325, pl. 7, figs. 2, 4.

1992 H. nabresinensis Futterer - Peza, 294, pl. 1, fig. 3.

Table 1. Morphometrical measures of samples of $H l$. lapeirousei described in literature

\begin{tabular}{|c|c|c|c|c|}
\hline $\mathrm{N}$ & SPECIMENS & $S a$ & Ia & $P 1-P 2 a$ \\
\hline 1 & Douvillé, 1893, tab. 24, fig. 10 & 340 & 419 & 16 \\
\hline 2 & Toucas, 1903 , p. 53 , fig. 83 & 140 & 207 & 8 \\
\hline 3 & Toucas, 1903 , p. 53 , fig. 84 & 122 & 137 & 8 \\
\hline 4 & Pleničar, 1975 , p.7, fig. 2 & 194 & 182 & 11 \\
\hline 5 & Parona, 1900 , tab. 1 , fig. 2 & 426 & 510 & 30 \\
\hline 6 & Goldfuss, 1840 , tab. 165 , fig. $5 \mathrm{c}$ & 52 & 95 & 4 \\
\hline 7 & Czabalay, 1982, tab. 24, fig. 1 & 287 & 349 & 21 \\
\hline 8 & Pons, 1977, tab. 25, fig. 1 & 21 & 38 & 2 \\
\hline 9 & Pons, 1977, tab. 25, fig. 2 & 97 & 145 & 7 \\
\hline 10 & Pons, 1977, tab. 17, fig. 1 & 390 & 754 & 36 \\
\hline 11 & Pleničar, 1994, tab. 2, fig. 6 & 351 & 574 & 22 \\
\hline 12 & Vicens, 1992, tab. 1, fig. 17 & 239 & 336 & 13 \\
\hline 13 & Vicens, 1992, tab. 1, fig. 19 & 87 & 133 & 7 \\
\hline 14 & Vicens, 1992, tab. 1, fig. 20 & 226 & 371 & 17 \\
\hline
\end{tabular}

$S a$ Shell area; $I a$ Inner area; $P 1-P 2 a$ Pillars area. The area's values are expressed in $\mathrm{mm}^{2}$ 
Taxonomical remarks: Futterer (1893) in the description of the $H l$. nabresinensis focused his attention specially on the external characters of this species. He described the cylindrical lower valve with a length of $270 \mathrm{~mm}$ and a diameter of 30 to $40 \mathrm{~mm}$. The shell is crossed by about 21 longitudinal and rounded costae, which are from 2 to $5 \mathrm{~mm}$ wide. The pillar $P 1$ is rounded and its base is wider than that of the pillars P2. Accordi et al. (1982) observed that the shell is crossed by rounded costae which include narrow canals. These canals are also crossed by thin ribs. The external shell presents weak concavities in correspondence to the pillars. The presence of a ligamental ridge is not mentioned by Futterer (1893) in his description of the holotype. This character is confirmed by personal observations on 300 lower valves of this species coming from the type locality Aurisina/Nabrežina.

The Futterer's description (1893) receives two years later the first objection from Douvillé (1895), who placed $\mathrm{Hl}$. nabresinensis as a synonym of Hippurites lapeirousei var. crassa because these characters were not enough to create a new species. Parona (1900) also observed the great similarity between $\mathrm{Hl}$. nabresinensis and $\mathrm{Hl}$. lapeirouse $i$ and the same author placed $H \mathrm{H}$. nabresinensis as a synonym of $\mathrm{Hl}$. lapeirousei in 1926 confirming the previous observations of Douvillé (1895). Also Schubert (1912) placed $\mathrm{Hl}$. nabresinensis as synonym of $\mathrm{Hl}$. lapeirousei var. crassa.

Kühn (1947) described a new species Hl. heritschi. Later, other authors discussed about the similarity between these species: Sladić-Trifunović $(1972,1978)$ analysed the taxonomical problem and Laviano (1985) summarized the observations about the differences between the three species, according to the previous authors (Lupu, 1976; Sladić-Trifunović, 1972, 1978; Accordi et al., 1982).

Distribution: the holotype described by Futterer (1893) has been found in the type locality Aurisina/Nabrežina (Karst of Trieste) in the limestones of the SantonianCampanian (Cucchi et al., 1987).

The transversal sections of the lower valves of the individuals of the species Hippuritella nabresinensis are presented on the plates $2,3 \mathrm{a}$ and $3 \mathrm{~b}$, the morphometrical measures of the same individuals on the tables 2 and 3 .

Table 2. Morphometrical measures of samples of Hl. nabresinensis described in literature

\begin{tabular}{|r|l|c|c|c|}
\hline N & \multicolumn{1}{|c|}{ SPECIMENS } & Sa & Ia & P1-P2a \\
\hline 1 & Accordi et al., 1982, tab. 4, fig. 10 & 135 & 113 & 11 \\
2 & Accordi et al., 1982, tab. 4, fig. 10 & 180 & 177 & 14 \\
3 & Futterer, 1893, tab. 22, fig. 3a & 235 & 608 & 37 \\
4 & Polšak, 1979, tab. 10, fig. 7 & 775 & 766 & 43 \\
5 & Polšak, 1979, tab. 10, fig. 7 & 779 & 947 & 56 \\
6 & Laviano, 1985, tab. 7, fig. 4 & 203 & 209 & 20 \\
7 & Czabalay, 1982, tab. 10, fig. 5 & 134 & 144 & 12 \\
8 & Sladić-Trifunović, 1972, tab. 12, fig. 1b & 284 & 361 & 21 \\
9 & Sladić-Trifunović, 1972, tab. 12, fig. 2b & 174 & 168 & 13 \\
10 & Accordi et al., 1990, tab. 1, fig. 5 & 884 & 877 & 90 \\
\hline
\end{tabular}

$S a$ Shell area; Ia Inner area; P1-P2a Pillars area. The area's values are expressed in $\mathrm{mm}^{2}$ 
Table 3. Morphometrical measures of samples of $H l$. nabresinensis coming from to Aurisina/Nabrežina (Karst of Trieste)

\begin{tabular}{|c|c|c|c|}
\hline $\mathrm{N}$ & $S a$ & $I a$ & $P 1-P 2 a$ \\
\hline 1 & 63 & 57 & 4 \\
2 & 485 & 365 & 29 \\
3 & 25 & 34 & 2.5 \\
4 & 26 & 38 & 2.5 \\
5 & 545 & 468 & 36 \\
6 & 491 & 381 & 31 \\
7 & 184 & 190 & 7 \\
8 & 229 & 244 & 20 \\
9 & 320 & 292 & 15 \\
10 & 65 & 86 & 5 \\
11 & 51 & 76 & 2 \\
12 & 895 & 905 & 72 \\
13 & 414 & 340 & 24 \\
14 & 89 & 104 & 3 \\
15 & 574 & 591 & 54 \\
16 & 526 & 770 & 33 \\
17 & 81 & 267 & 19 \\
18 & 510 & 448 & 40 \\
19 & 957 & 926 & 72 \\
20 & 268 & 174 & 15 \\
21 & 121 & 240 & 6 \\
22 & 175 & 283 & 14 \\
23 & 357 & 401 & 36 \\
24 & 124 & 81 & 11 \\
\hline
\end{tabular}

\begin{tabular}{|c|c|c|c|}
\hline $\mathrm{N}$ & Sa & Ia & P1-P2a \\
\hline 25 & 1029 & 1524 & 63 \\
26 & 275 & 296 & 17 \\
27 & 2405 & 1729 & 137 \\
28 & 589 & 531 & 34 \\
29 & 502 & 584 & 51 \\
30 & 285 & 330 & 22 \\
31 & 283 & 231 & 16 \\
32 & 515 & 533 & 39 \\
33 & 485 & 628 & 38 \\
34 & 98 & 70 & 4 \\
35 & 159 & 191 & 13 \\
36 & 454 & 561 & 36 \\
37 & 47 & 52 & 3 \\
38 & 259 & 244 & 16 \\
39 & 456 & 536 & 29.5 \\
40 & 239 & 394 & 25 \\
41 & 152 & 114 & 5.5 \\
42 & 64 & 84 & 4 \\
43 & 50 & 37 & 3.5 \\
44 & 85 & 77 & 4 \\
45 & 103 & 62 & 6 \\
46 & 178 & 210 & 20 \\
47 & 71 & 93 & 7 \\
48 & 108 & 121 & 9 \\
\hline
\end{tabular}

Sa Shell area; Ia Inner area; P1-P2a Pillars area. The area's values are expressed in $\mathrm{mm}^{2}$

\section{Hippuritella heritschi (Kühn, 1947)}

1908 Hippurites colliciatus Woodward - Schmidt, 238.

1934 Hippurites (Orbignya) lapeirousei Goldfuss - Milovanović, 223, fig. 18. 1951 H. (Orb.) nabresinensis Futterer - Pejović, 94, pl. 1, fig. 2; pl. 2, fig. 2; pl. 3, fig. 2.

1960 H. heritschi Kühn - Kühn, 48.

1962 H. heritschi Kühn - Kaumanns, 305, pl. 2, fig. 4; text. fig. 6.

1970 H. heritschi Kühn - Pamouktchiev, 48.

1978 H. heritschi Kühn - Sladić-Trifunović, 422, pl. 1-8, text. fig. 1, 2. 1979 Hippuritella heritschi (Kühn) - Pamouktchiev, 220, pl. 7, figs. 1-3. 1982 Hippurites heritschi Kühn - Czabalay, 79, pl. 13, fig. 14; pl. 18, fig. 1. 1992 Hippurites heritschi Kühn - Caffau et al., P1. 1, fig. 1.

1994 Hippuritella heritschi (Kühn) - Pleničar, 51, pl. 2, fig. 7; pl. 3, fig. 1, 2.

Taxonomical remarks: the conical lower valve is crossed by longitudinal costae, separated by rounded canals. In some specimens the shell is very thick and can be as large as $27 \mathrm{~mm}$, as described by Sladić-Trifunović (1978). The pillars are 
triangular with approximately the same dimensions. The upper valve, which was described for the first time by Sladić-Trifunović (1978), is covered by polygonal pores and radially crossed by canals. The ligamental ridge is absent. SladićTrifunović (1978) analysed the taxonomical problem concerning the similarity of this species with the $\mathrm{Hl}$. lapeirouse $i$ and $H \mathrm{H}$. nabresinensis. He also observed that in all stages of the ontogenetical development, the shell of $\mathrm{Hl}$. heritschi is always thick. In our opinion, such character is also present in $\mathrm{Hl}$. nabresinensis. According to Pejović and Kühn (1960), Laviano (1985) considered the shape and dimension of the shell and pillars as distinctive characters between $\mathrm{Hl}$. nabresinensis and $\mathrm{Hl}$. heritschi.

Table 4. Morphometrical measures of samples of $\mathrm{Hl}$. heritschi described in literature

\begin{tabular}{|r|l|c|c|c|}
\hline N & \multicolumn{1}{|c|}{ SPECIMENS } & Sa & Ia & P1-P2a \\
\hline 1 & Laviano, 1985, tab. 9, fig. 1 & 1873 & 1550 & 101 \\
2 & Caffau et al., 1992, tab. 1, fig. 1 & 966 & 657 & 56 \\
3 & Accordi et al., 1987, tab. 2, fig. 6 & 1595 & 1689 & 127 \\
4 & Pejović, 1951, tab. 3, fig. 2 & 2706 & 2099 & 168 \\
5 & Pejović, 1951, tab. 1, fig. 2 & 1863 & 1039 & 97 \\
6 & Sladić-Trifunović, 1978, tab. 1, fig. 2 & 1790 & 1880 & 62 \\
7 & Sladić-Trifunović, 1978, tab. 4, fig. 3 & 1299 & 1124 & 63 \\
8 & Sladić-Trifunović, 1978, tab. 6, fig. 3 & 557 & 380 & 31 \\
9 & Sladič-Trifunović, 1978, tab. 6, fig. 2 & 978 & 820 & 64 \\
10 & Sladić-Trifunović, 1978, fig. 1 & 1061 & 631 & 54 \\
11 & Pleničar, 1994, tab. 3, fig. 1 & 2214 & 2115 & 143 \\
\hline
\end{tabular}

Sa Shell area; Ia Inner area; $P 1-P 2 a$ Pillars area. The area's values are expressed in $\mathrm{mm}^{2}$

Table 5. Morphometrical measures of samples of $\mathrm{Hl}$. heritschi from Stranice (samples 1-2) and from Senožeče (samples 3-15), Slovenia

\begin{tabular}{|r|c|c|c|}
\hline $\mathrm{N}$ & Sa & Ia & P1-P2a \\
\hline 1 & 747 & 687 & 37 \\
2 & 572 & 483 & 43 \\
3 & 575 & 549 & 46 \\
4 & 121 & 88 & 12 \\
5 & 419 & 375 & 30 \\
6 & 462 & 378 & 38 \\
7 & 213 & 149 & 14 \\
8 & 559 & 482 & 42 \\
9 & 415 & 397 & 20 \\
10 & 427 & 384 & 25 \\
11 & 251 & 201 & 16 \\
12 & 110 & 114 & 8 \\
13 & 945 & 1088 & 74 \\
14 & 568 & 463 & 51 \\
15 & 755 & 381 & 45 \\
\hline
\end{tabular}

Sa Shell area; Ia Inner area; P1-P2a Pillars area. The area's values are expressed in $\mathrm{mm}^{2}$ 
Disribution: Hl. heritschi was found in Maastrichtian in Katschberg, near the St. Bartholomä in Austria (Sladić-Trifunović, 1978). Furthermore, in the Upper Campanian-Lower Maastrichtian in the zone of Valencia in Spain, in Italy in the Apennines in the zone of Maiella Mt. and Matese Mt. and in Sicilia (Pachino) (Pons \& Sirna, 1992).

The transversal sections of the lower valves of the individuals of the species Hippuritella heritschi are presented on the plates 4 and 5, the morphometrical measures of the same individuals on the tables 4 and 5 .

\section{Biometrical analysis}

We recall that the examined material for this study included: a) specimens which are already described in literature and b) specimens coming from different outcrops (tab. 3a, 3b, 5; pl. 3, 5).

In the first case, the morphometrical values were obtained from published illustrations (tab. 1, 2, 4; pl. 1, 2, 4). In the latter case, the lower valves were cut and their transversal sections were subjected to morphometric measurements. Some characters, which are related by their biological functions (Reali, 1992) were selected for this biometrical study and their areas were measured as shown in Fig 1a. These morphometrical values are: a) the surface mantle or shell area $(S a)$ responsible for the incoming water flux and the entrance of nutrients in the internal cavity; b) the area of the internal cavity ( $I a$ ) which contains the organic tissues where assimilation of nutrients takes place; c) the surface of pillars $(P 1-P 2 a)$, related to the expulsion of metabolic residues. Taking into acount that pillars and mantle thickness are in close biological relationship with the internal cavity (Skelton, 1976), P1-P2a and Sa values were plotted against $I a$.
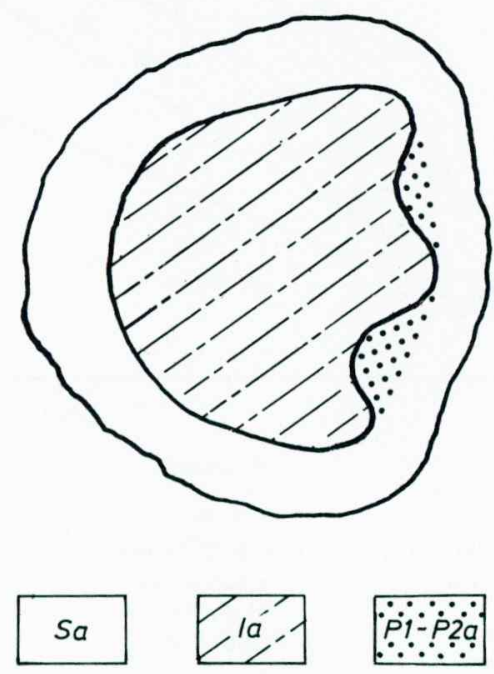

Fig. 1a. Transversal section of a lower valve where the measured areas are indicated 
In all the graphs, the regression lines corresponding to $\mathrm{Hl}$. lapeirousei, $\mathrm{Hl}$. nabresinensis and $\mathrm{Hl}$. heritschi were indicated as a, b, and c, respectively.

\section{Results and final consideration}

In all the cases, the regression lines of $S a$ versus $I a$ and $P 1-P 2 a$ versus $I a$ (figs. 1-4) have a dispersion coefficient ( $r$ squared $=R$ ) close to the unit.

This values indicates a very good correlation between these morphological characters, also including specimens coming from different geographical areas. In detail, in graph fig. 1 the slope of the regression lines for the species $\mathrm{Hl}$. nabresinensis and $\mathrm{Hl}$. heritschi are 0.85 and 0.91 respectively while for $\mathrm{Hl}$. lapeirousei is 0.59 . In graph fig. 2, the regression lines for $\mathrm{Hl}$. nabresinensis and $\mathrm{Hl}$. heritschi have a slope of 0.059 and 0.057 respectively while for $\mathrm{Hl}$. lapeirousei is 0.046 . Comparing these values (graphs figs. 1 and 2) it can be seen that the slope of the regression line for the species $\mathrm{Hl}$. lapeirousei differs from the other two, which are very similar between them.

The same values for the collected samples of the species $H l$. nabresinensis and $\mathrm{Hl}$. heritschi (graph fig. 3: slope values of 1.03 and 0.87 respectively) are very similar

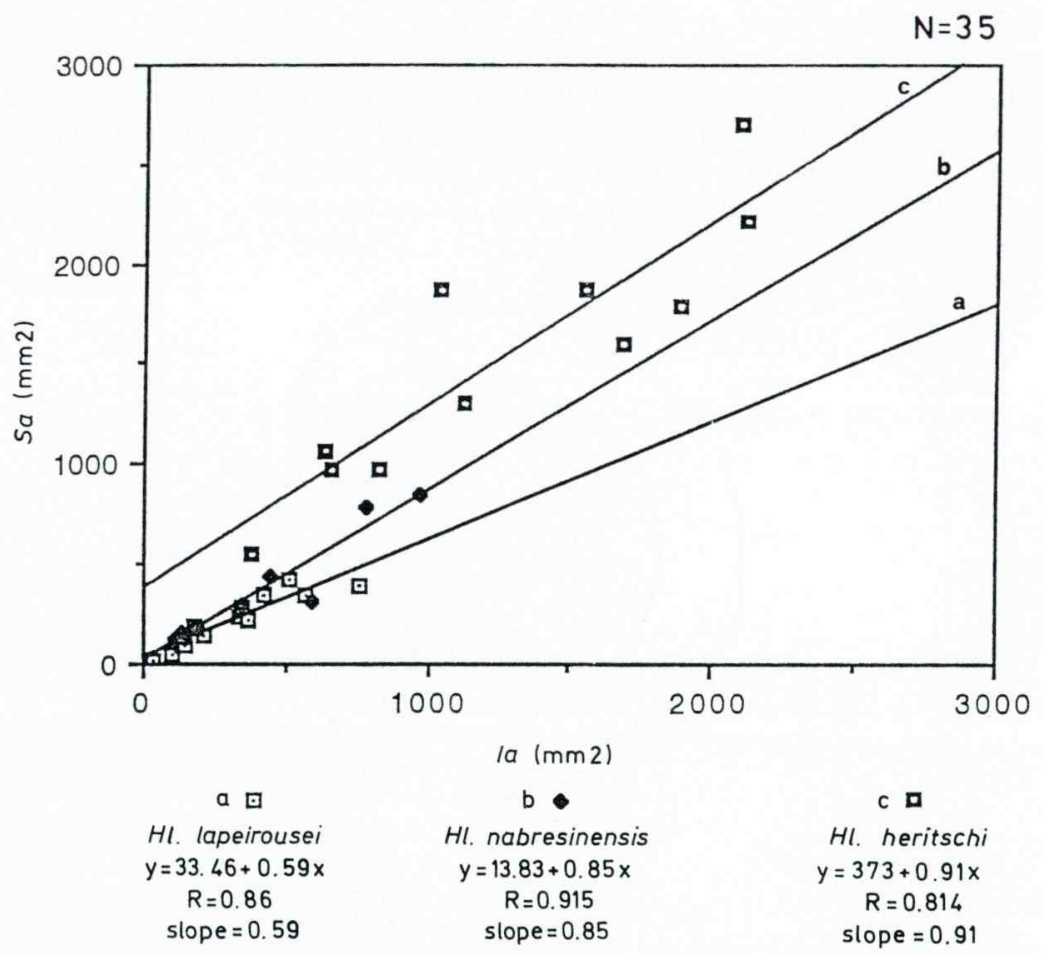

Fig. 1. Shell area (Sa) versus inner area (Ia) of samples of the three described in literature (see data on tables 1, 2, 4). Regression values and disperssion coefficient are shown 


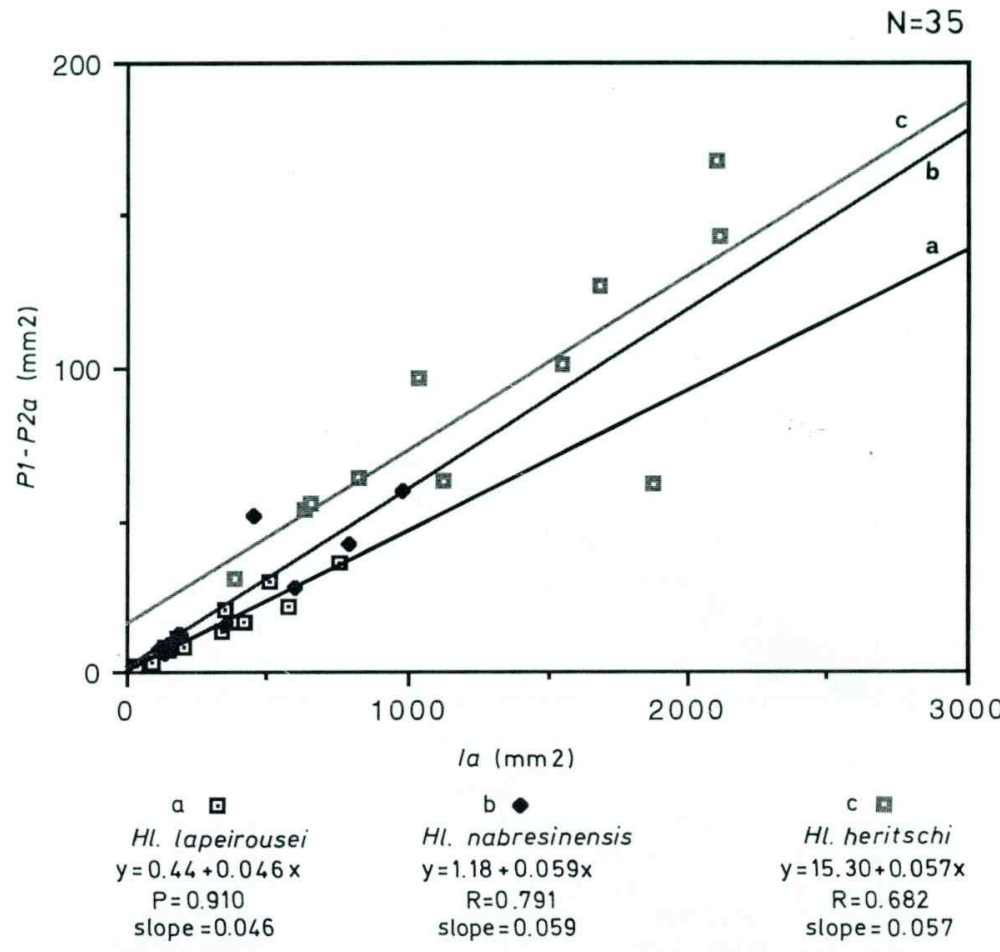

Fig. 2. Pillars area (P1-P2a) versus inner area (Ia) of samples of the three described in literature (see data on tables $1,2,4)$. Regression values and disperssion coefficient are shown

to those of the specimens described in literature (graph fig. 1: 0.85 and 0.91 respectively). The same can be said comparing the slope of the regression lines in graphs figs. 4 and 2 .

Thus, combining the results from the analysis of the specimens described in literature and those collected, it is possible to conclude that the biological characters of $\mathrm{Hl}$. lapeirousei are clearly different from those of the other two species. On the contrary, the characters of $\mathrm{Hl}$. nabresinensis and $\mathrm{Hl}$. heritschi are very similar between them. This fact leads to the idea that these two species could be the same. In fact, new morphometrical analysis are in process in order to confirm this hypothesis.

\section{Acknowledgements}

This works has been carried out with the grant of the Chair for Geology and Paleontology of the University in Ljubljana, of the Slovene Academy of Sciences and Arts and of Istituto di Geologia e Paleontologia dell'Università di Trieste. We are particulary indebted to Dr. Bogdan Jurkovšek, who kindly lent us some rudist samples from his collection and to Dr. María Inés Gutiérrez of I.C.G.B. for translation into English. 


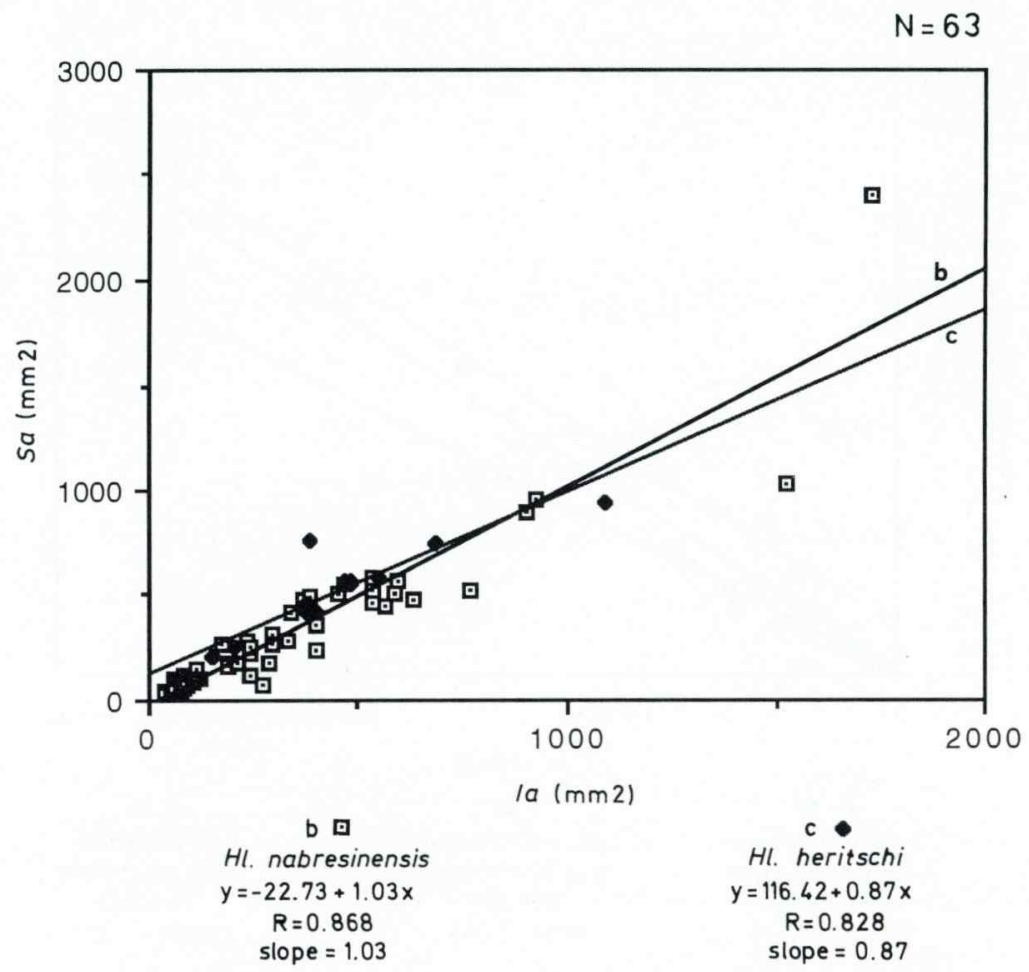

Fig. 3. Shell area (Sa) versus inner area (Ia) of samples of Hl. nabresinensis and $\mathrm{Hl}$. heritschi recently found in outcrops (see data on tables 3 ,

5). Regres-sion values and disperssion coefficient are shown

We are very grateful to Prof. Nevio Pugliese of Università di Trieste for his useful suggestions and for reading critically the manunscript.

Warmest thanks are extended to all.

\section{References}

Accordi, G., Carbone, F. \& Sirna, G. 1982: Relationship among tectonic setting, substratum and benthonic communities in the Upper Cretaceous of northeastern Matese (Molise, Italy). - Geologia Rom., 21, 775-793, 16 figs., 5 pls., Roma.

Accordi, G., Carbone, F. \& Sirna, G. 1987: Some affinities between the Ionian Islands and the Apulian Upper Cretaceous Rudist facies. - Mem. Soc. Geol. It., 40, 163-173, 1 tab., 4 pls., Roma.

Accordi, G., Carbone, F., Cestari, R., Reali, S. \& Sirna, G. 1990: Cretaceous rudist colonization in North-Eastern Matese. - In: Rudist Communities and Substratum in the Matese Mounts, Molise, Italy, 2nd International Conference on Rudists, Rome-Bari Oct. 1990, 1930, 6 pls., Roma.

Caffau, M., Pirini-Radrizzani, C., Pleničar, M. \& Pugliese, N. 1992: Rudist fauna and microfossils of the late Senonian (Monte Grisa area, Karst of Trieste, Italy). - Geologia Rom., 28, 1 fig., 1 tab., Roma.

Czabalay, L. 1982: La Fauna des rudistes des environs de Sumes (Hongrie). Geol. Hung., ser. Paleont., 41, Budapest. 


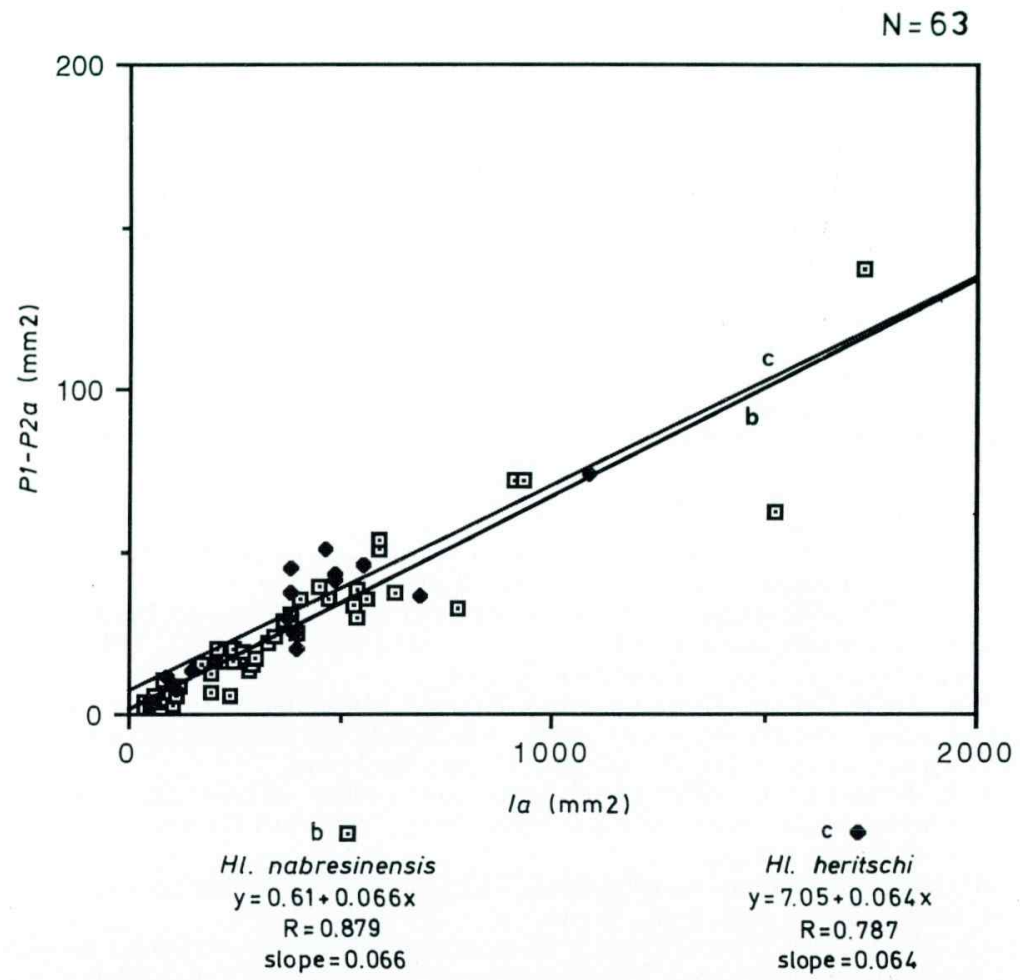

Fig. 4. Pillars area (P1-P2a) versus inner area (Ia) of samples of $\mathrm{Hl}$. nabresinensis and $H l$. heritschi recently found in outcrops (see data on tables $3,5)$. Regression values and disperssion coefficient are shown

Cucchi, F., Pirini-Radrizzani, C. \& Pugliese, N. 1987: The carbonate stratigraphic sequence of the Karst of Trieste (Italy). - Mem. Soc. Geol. It., 40, 35-44, 1 fig., 2 tab., Roma.

Douvillé, H. 1891-97: Études sur les Rudistes. Révision des principales espéces d'Hippurites. - Mém. Soc. Géol. France, Pal. 1-6, Mém., 6, 1-230, 34 pls., Paris.

Futterer, C. 1893: Über Hippuriten von Nabresina. - Zeitsch. D. g. G., 45, 477-488. Berlin.

Goldfuss, A. 1840: Petrefacta Germaniae - 2. Theil, Divisio quarta, Düsseldorf.

Kaumanns, M. 1962: Zur Stratigraphie und Tektonik der Gosauschichten des Kainachbeckens. - Sitzungsberg. Österr. Akad. Wiss. Math.-naturwiss. Kl., Abt. I, 171/8-10, 289-314, 8 figs., pls. Wien.

Kühn, O., 1947: Zur Stratigraphie und Tektonik der Gosauschichten. - Sitz. Österr. Ak. Wiss. Math., 156, 181-200, Wien. furt.

Kühn, O., 1960: Die Rudistenfauna von Wietersdorf in Kärnten, 70, (150), I, 47-50, Klagen-

Laviano, A. 1985: Paleontological description on some Rudists from the Upper Cretaceous of Ostuni (BR-Italy). - Riv. It. Pal. Strat., 91 (3), 321-356, 1 fig., 10 pls., Milano.

Lupu, D. 1969: Fauna de rudisti senoniani de la Remeti (Apuseni de Nord). Studii cerc. geol. geof. geogr., Ser. geologie, 14, 1, 205-224, 2 pls., 171 figs. Bucarest.

Lupu, D. 1976: Contribution à l'étude des Rudistes sénoniens des Monts Apuseni. - Mem. Inst. Géoph., 24, 83-151, 1 pl., 3 figs. Bucarest.

Milovanović, B. 1934: Rudistes de la Yougoslavie. 1. Serbie orientale, occidentale et Ancienne Raška. - Ann. Géol. Péninsule Balcanique, 12, 1, 178-254, Beograd. 
Pamouktchiev, A. 1970: Vrhu prisstvieto na mastriht pri Kainachbeckens (Austrija). God. Sof. univ., 62, Sofija.

Pamouktchiev, A. 1979: Faune des Rudistes du Maastrichtien en Bulgarie (de l'arrondissement de Breznik, 7, III; - Ann; Univ; Sofija „Kliment Ohridski“, Fac. géol. géogr., 73/1, 213-246, 9 pls., Sofija.

Parona, C. F. 1900: Sopra alcune Rudiste senoniane dell'Appennino meridionale. - Mem. R. Acc. Sc. Torino, 50 (2), 1-23, 2 pls., Torino.

Parona, C. F. 1926: Ricerche sulle Rudiste e su altri fossili del Cretaceo superiore del Carso Goriziano e dell'Istria. - Mem. Ist. Geol. R. Univ. Padova, 7, 1-56, 8 figs., 6 pls., Padova.

Pejović, D. 1951: Nekoliko rudista iz senonskih naslaga okoline Pirota. - Zbornik radova Geol. Inst., 16/2, 91-97, 3 pls., annex 1-3, Beograd.

Pejović, D. \& Kühn, O. 1960: Das Alter der Rudistenkalke von Pirot. - Sitz. Öster. Ak. Wiss. Math., 7, 136-138, 1 fig., Wien.

Peza, L. 1992: Senonian rudist from Guri Pishkashit (West from Ohrid lake), Albania. Geologica Rom., 28, 7 figs., 1 tab., 2 pls., Roma.

Pleničar, M. 1975: Hippuritidae of Nanos and the Trieste-Komen plain. - Razprave SAZU, 18, 85-114, 23 pls., Ljubljana.

Pleničar, M. 1994: Hippuritids from the Upper Cretaceous rudistid reef near Stranice and Lipa (NE Slovenia). - Razprave SAZU, 35, 43-63, 3 pls., Ljubljana.

Polšak, A. 1979: Stratigraphy and Paleogeography of the Senonian Biolithitic Complex at Donje Orešje (Mt. Medvednica, North Croatia). - Acta Geologica JAZU 9/6, Prirodoslovna istraživanja, 42, 195-231, 17 pls., 2 annexes, Zagreb.

Pons, J. M. 1977: Estudio Estratigrafico y Paleontologico de los Yacimientes de Rudistidos del Cretacico Sup. del Prepirineo de la Prov. de Lerida. - Universidad Autonoma de Barcelona, Publicaciones de Geologia, 3, 105 pp., 87 pls., Barcelona.

Pons, J. M. \& Sirna, G. 1992: Upper Cretaceous rudists distribution in the Mediterranean Tethys: comparison between platforms from Spain and south Central Italy. - Geologica Rom., 28, 341-349, 2 figs., Roma.

Reali, S., 1992: Preliminary morphometric analysis for Hippuritids taxonomy. - Geologia Rom., 28, 91-103, 8 figs., 3 tab., 1 pl., Roma.

Sánchez, M. V. 1981: Hippuritidae y Radiolitidae (Bivalvia). Catalogo de especies. Universidad autonoma de Barcelona. Publicaciones de geologia, 15, 1-228, Barcelona.

Schmidt, W. 1908: Die Kreidebildungen der Kainach. - Jb. geol, R. A., 58, 223-246, Wien. Schubert, R. 1912: Geologischer Führer durch die Nördliche Adria. - Sammlung geol. Führer, 17, 1-213, Berlin. Oslo.

Skelton, P. W. 1976: Functional morphology of the Hippuritidae. - Lethaia, 9, 83-100,

Sladić-Trifunović, M. 1972: Senonian limestones with Orbitoides and rudist from Kozluk (North-eastern Bosnia). - Ann. Géol. Pénin. Balk., 37, 11-150, 8, pls. Beograd.

Sladić-Trifunović, M. 1978: Hippurites heritschi and the Maastrichtian rudist horizonts in the Senonian sediments at St. Bartholomä (Kainachbecken, Austria). - Ann. Géol. Pénin. Balk., 42, 421-445, 7 pls., 8 figs., Beograd.

Toucas, A. 1903-1904: Études sur la clasification et évolution des Hippurites. Mém. Soc. Géol. France, 30, 65-128, 17 pls., Paris.

Vicens, E. 1992: Intraspecific variability in Hippuritidae in the Southern Pyrenees, Spain: taxonomic implication. - Geologica Rom., 28, 119-161, 13 figs., 13 tab., 8 pls., Roma.

Vidal, L. M. 1878: Note acerca del sistema Cretaceo de los Pireneos de Cataluña. - Boletin Com. ejecutiva del mapa geol. de España, 4, 257-372, 1-11 textfigs., 7 pls., Madrid. 

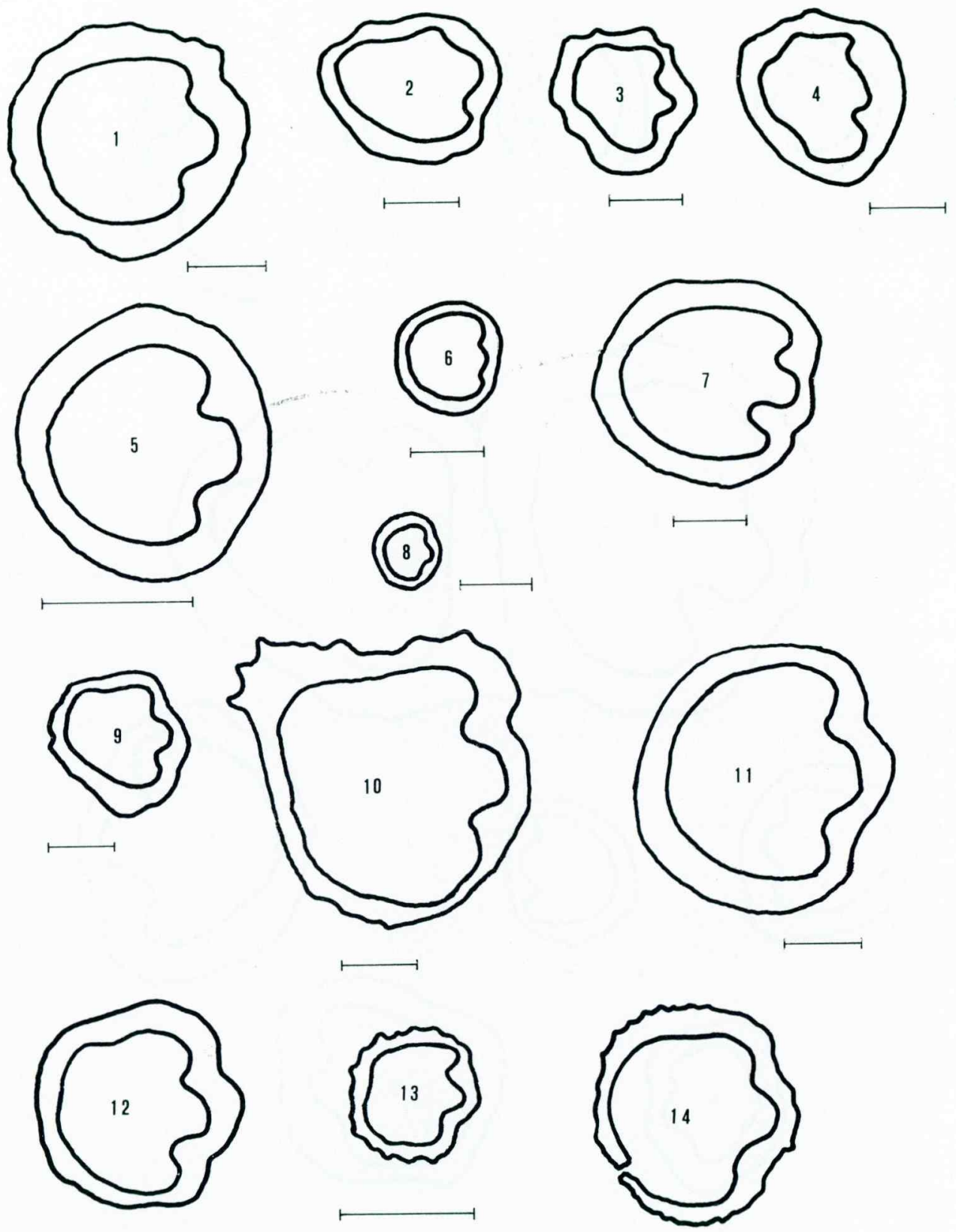

Plate 1

Hl. lapeirousei, transversal sections of lower valves of individuals described in literature, measured and numbered. Bar scale: $10 \mathrm{~mm}$ 

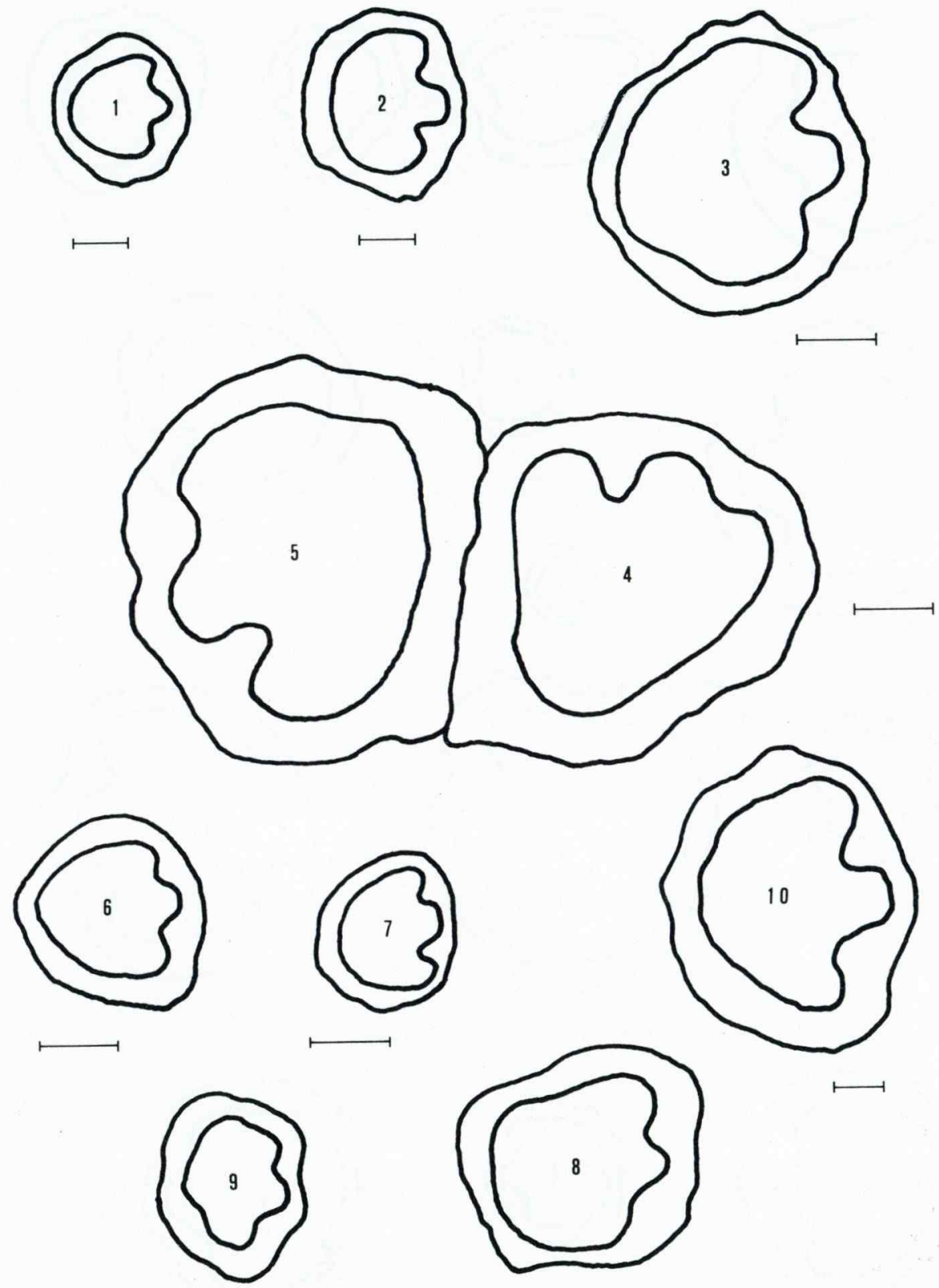

Plate 2

$H l$. nabresinensis, transversal sections of lower valves of individuals described in literature, measured and numbered. Bar scale: $10 \mathrm{~mm}$ 


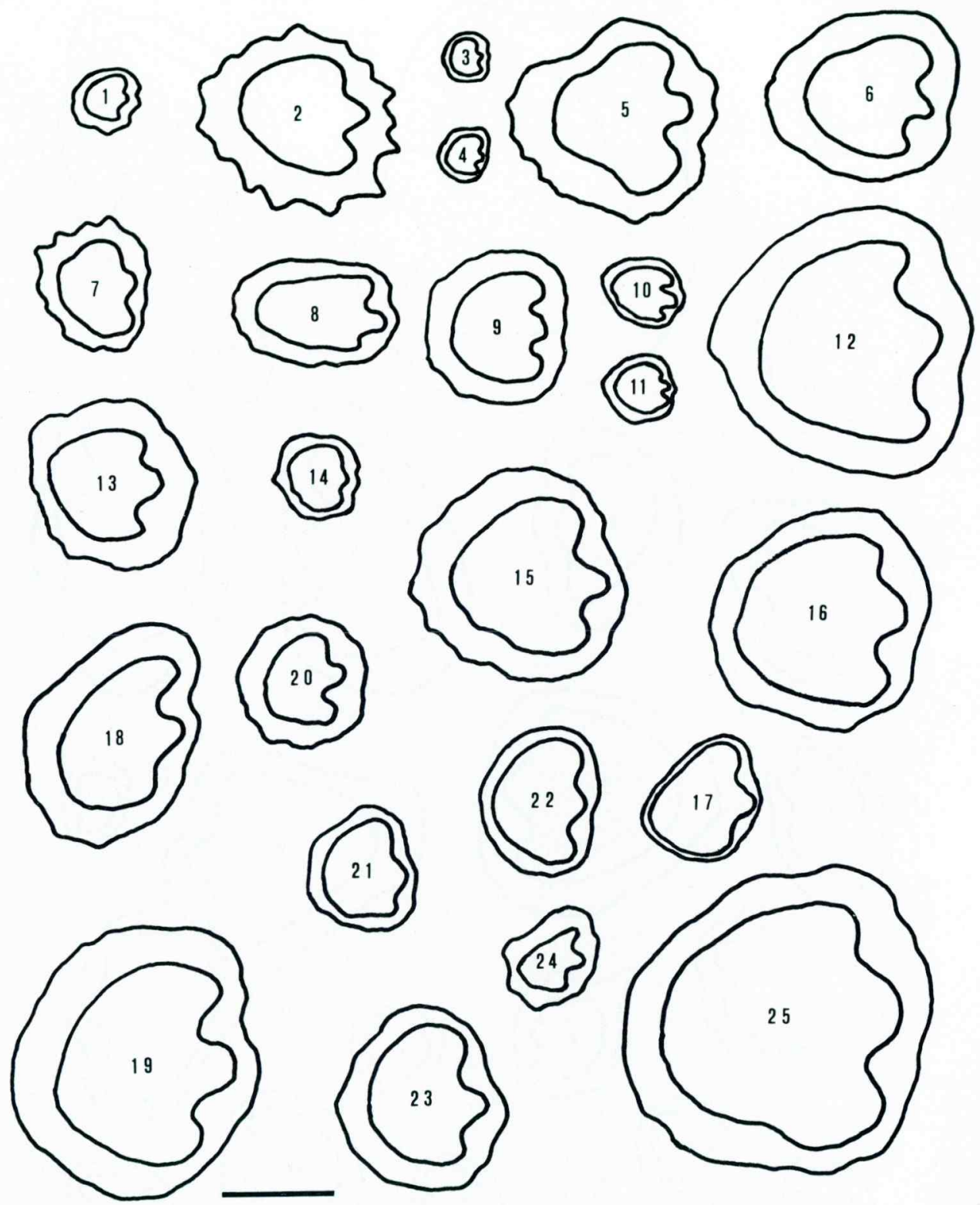

Plate 3a

Hl. nabresinensis, transversal sections of the lower valves of individuals that belong to Aurisina/Nabrežina (Karst of Trieste), measured and numbered. Bar scale: $20 \mathrm{~mm}$ 

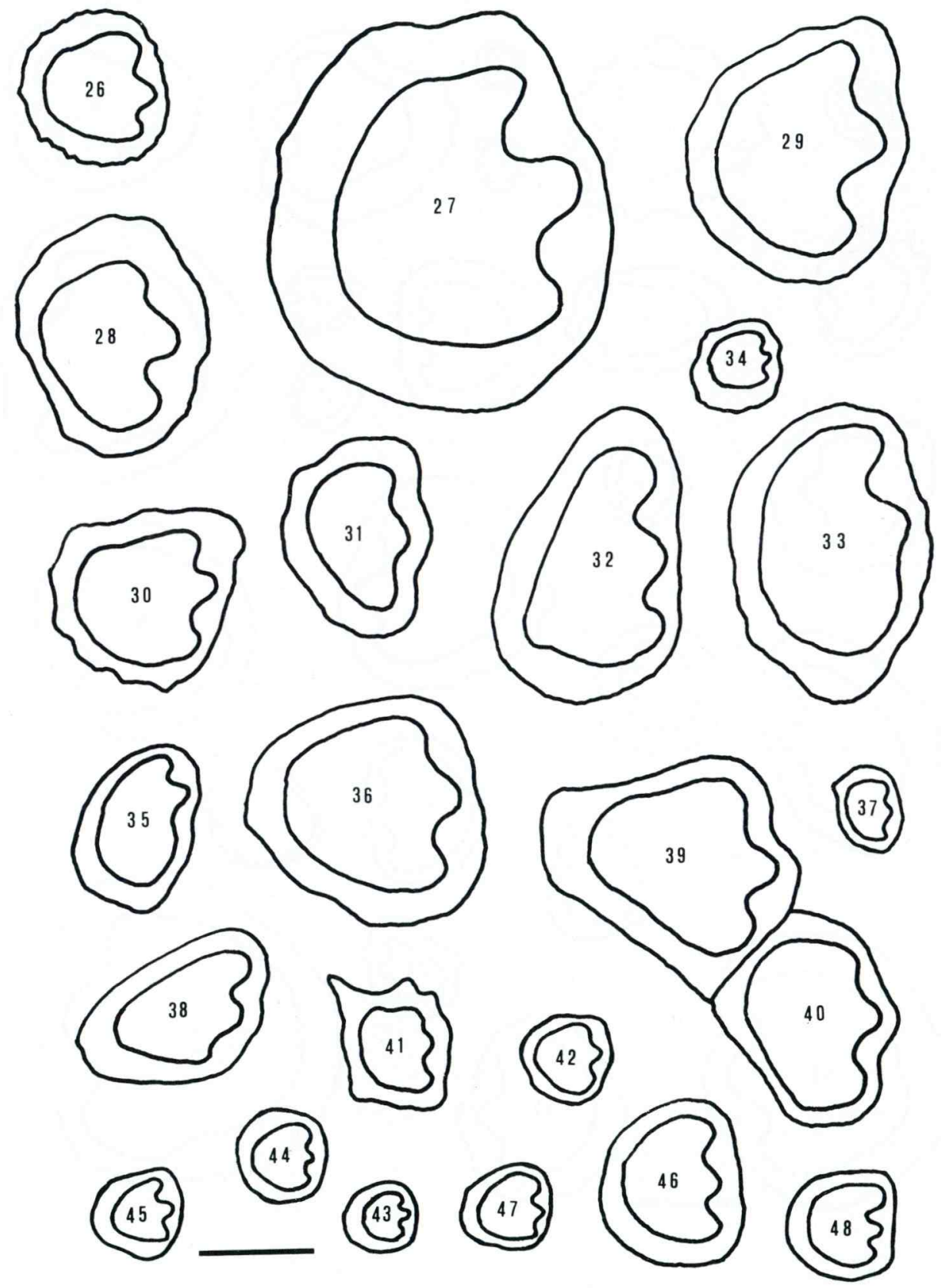

Plate $3 \mathrm{~b}$

Hl. nabresinensis, transversal sections of the lower valves of individuals that belong to Aurisina/Nabrežina (Karst of Trieste), measured and numbered. Bar scale: $20 \mathrm{~mm}$ 


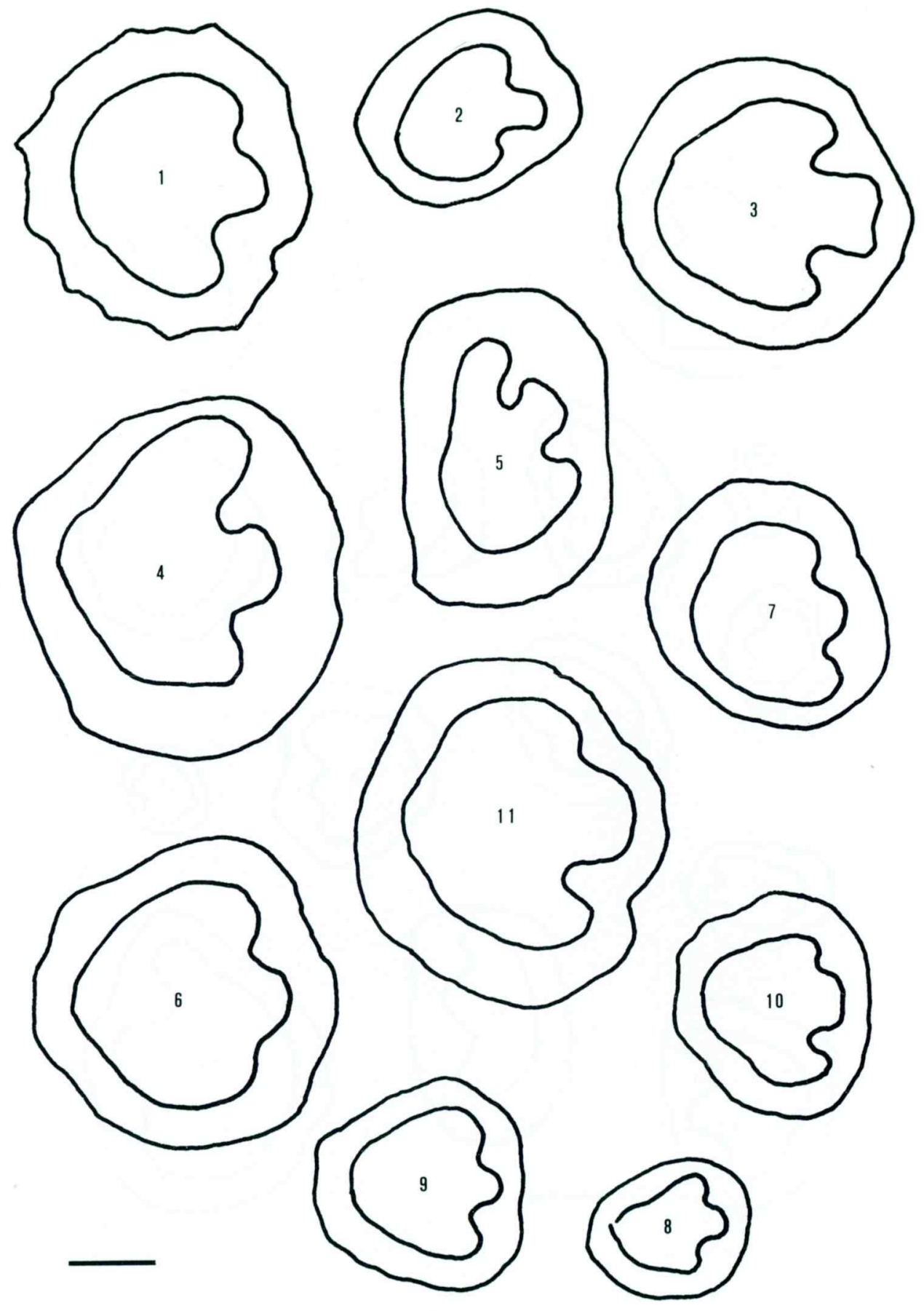

Plate 4

$H l$. heritschi, transversal sections of lower valves of individuals described in literature, measured and numbered. Bar scale: $20 \mathrm{~mm}$ 

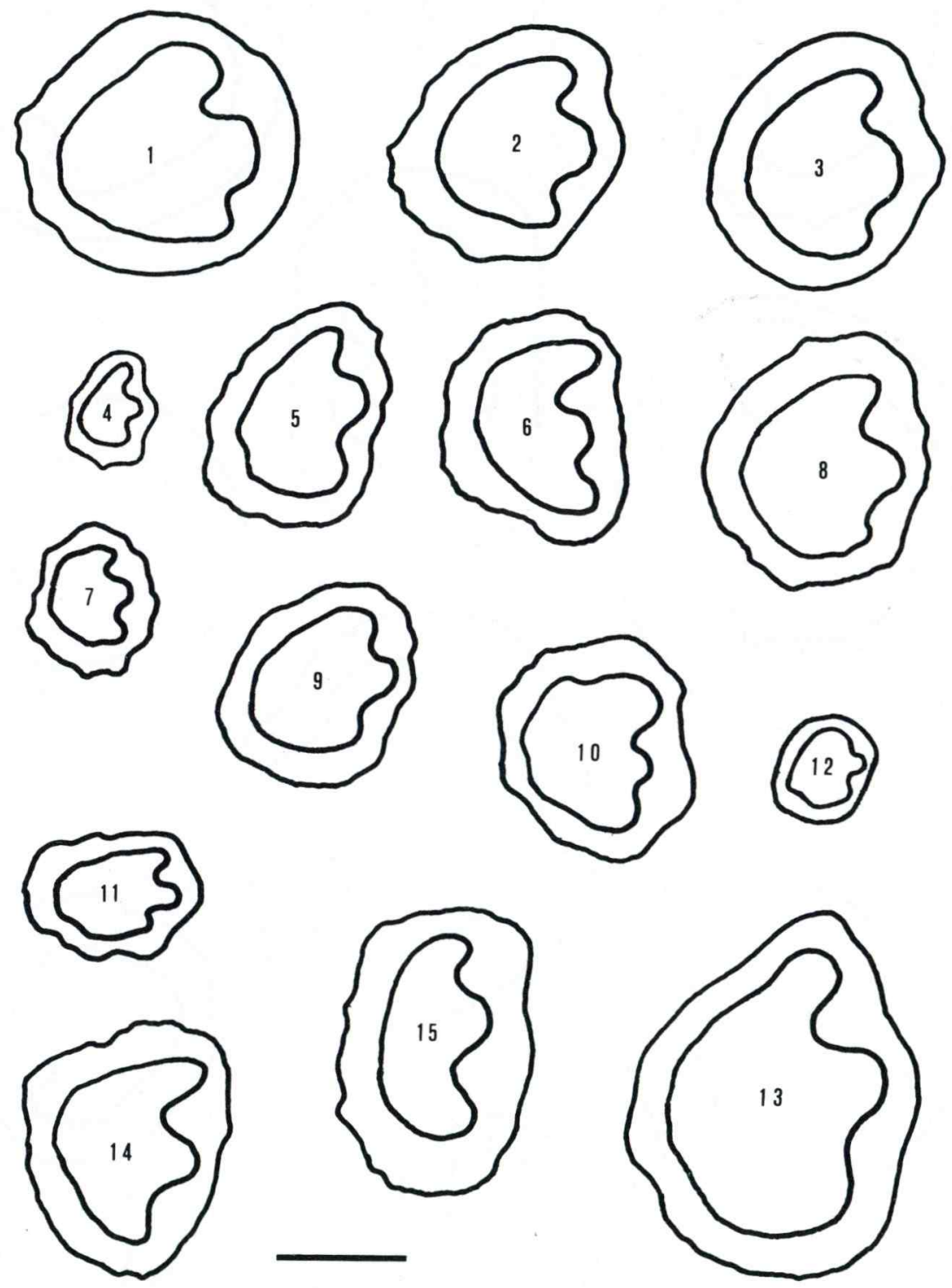

Plate 5

$H l$. heritschi, transversal sections of lower valves of individuals from Stranice (samples 1-2) and fromSenožeče (samples 3-15) measured and numbered. Bar scale: $20 \mathrm{~mm}$ 